\title{
Agricultural management and cultivation period alter soil enzymatic activity and bacterial diversity in litchi (Litchi chinensis Sonn.) orchards
}

\author{
Yu-Pei Chen ${ }^{1,2}$, Chia-Fang Tsai ${ }^{3}$, Asif Hameed ${ }^{3}$, Yu-Jen Chang ${ }^{4}$ and Chiu-Chung Young ${ }^{3,5^{*}}$ (1)
}

\begin{abstract}
Background: Agricultural management and temporal change including climate conditions and soil properties can result in the alteration of soil enzymatic activity and bacterial community, respectively. Therefore, different agricultural practices have been used globally to explore the soil quality. In this study, the temporal variations in soil property, enzymatic activity, and bacterial community at three successive trimester sampling intervals were performed in the soil samples of litchi orchards that were maintained under conventional and sustainable agricultural practices.

Results: Agricultural management found to significantly influence arylsulfatase, $\beta$-glucosidase, and urease activities across time as observed by repeated-measures analysis of variance. Shannon and Simpson diversity indices, and the relative abundance of predominant Acidobacteria and Proteobacteria were significantly influenced by temporal change but not agricultural management. This suggested that soil enzymatic activity was more susceptible to the interaction of temporal change and agricultural management than that of the bacterial community. Multiple regression analysis identified total nitrogen, EC, and phosphorus as the significant predictors of acid phosphatase, arylsulfatase, and $\beta$-glucosidase for explaining 29.5-39\% of the variation. Moreover, the soil pH and EC were selected for the SOBS, Chao, ACE, and Shannon index to describe 33.8\%, 79\% of the variation, but no significant predictor was observed in the dominant bacterial phyla. Additionally, the temporal change involved in the soil properties had a greater effect on bacterial richness and diversity, and enzymatic activity than that of the dominant phyla of bacteria.

Conclusions: A long-term sustainable agriculture in litchi orchards would also decrease soil pH and phosphorus, resulting in low $\beta$-glucosidase and urease activity, bacterial richness, and diversity. Nevertheless, application of chemical fertilizer could facilitate the soil acidification and lead to adverse effects on soil quality. The relationship between bacterial structure and biologically-driven ecological processes can be explored by the cross-over analysis of enzymatic activity, soil properties and bacterial composition.
\end{abstract}

Keywords: Agricultural management, Temporal change, Soil enzymes, Bacterial community, Bacterial diversity

\section{Background}

Soil enzymatic activities and microorganisms involved in soil biochemical processes have been suggested as indicators of soil quality. Nevertheless, soil enzymes are sensitive to certain environments and conditions in soil due

\footnotetext{
*Correspondence: ccyoung@mail.nchu.edu.tw

${ }^{3}$ Department of Soil and Environmental Sciences, National Chung Hsing

University, Taichung 40227, Taiwan

Full list of author information is available at the end of the article
}

to the multivariate turn-over times of enzymes (Schimel et al. 2017). In contaminated soils, $\beta$-glucosidase associated with the carbon cycle could be a biological indicator of soil health (Dai et al. 2018). This was also reflected in the arylsulfatase activity of heavy metal contaminated soils (Xian et al. 2015). Moreover, soil enzyme activity can directly inspect the transformation and fertility level of soil elements and nutrients. An overall increasing trend of soil enzymatic activity was observed with long-term rice cultivation in mudflat soil, attributed 
to salt desalination and organic matter accumulation (Zhang et al. 2019). Thus, soil enzymes are imperative in the evaluation of the ecological health of the terrestrial ecosystem.

On the other hand, much attention has been devoted to the relationship between soil microbial abundance and diversity, and soil properties (Bakker et al. 2018; Murphy et al. 2016). Several environmental factors including agricultural management, soil $\mathrm{pH}$, organic carbon, nitrogen, and temporal change can shift the soil microbial population (Kivlin and Hawkes 2016; Shigyo et al. 2019). A considerable variation in microbial community structure was observed between organically and conventionally managed soils because of the differences in the nutrient inputs and agronomic practices (Arcand et al. 2017; Bakker et al. 2018; Chen et al. 2018). Microbial carbon use efficiency can be affected by microbial communities through altering agricultural management (Arcand et al. 2017). This results from the crop residue decomposition between the organically and conventionally agricultural practices. Besides, soil $\mathrm{pH}$ was assumed to be the main driver for the prokaryotic community structure (Fierer and Jackson 2006; Lammel et al. 2018; Lauber et al. 2009; Shen et al. 2019). It can directly affect the enzymatic activity and bacterial composition or indirectly influence the solubility of different elements such as phosphorus, aluminum, iron, copper, molybdenum, and zinc (Lammel et al. 2018).

The effect of temporal dynamic including climate conditions and soil properties on soil enzymatic activity and microbial community is important for improving ecosystem management (Armstrong et al. 2016; Park et al. 2015; Shigyo et al. 2019). Several studies have been published on a low bacterial abundance in the summer (Jung et al. 2012; Rasche et al. 2011). The contribution of seasonal changes to microbial communities has a greater effect than that of spatial heterogeneity in cool-temperature montane forests (Shigyo et al. 2019). Additionally, temporal variability involved in temperature change can affect the soil spinach rhizosphere microbial community (Mark Ibekwe et al. 2017). Kivlin and Hawkes' study indicated that bacterial richness and diversity were influenced by the interaction of vegetation type and time (Kivlin and Hawkes 2016).

Litchi (Litchi chinensis Sonn.) is a tropical fruit with high commercial value cultivated in tropical and subtropical regions (Ray 2002). Fruit and seeds of litchi reportedly exhibit anticancer, antibacterial and antiviral features (Ibrahim and Mohamed 2015). According to conventional management, clean tillage can control the understory weed to prevent the competition of nutrients between fruits and weed; however, this can result in deterioration of the soil structure and lead to soil erosion and nutrient loss (Liu et al. 2013). Furthermore, the longterm application of chemical fertilizer has been demonstrated to cause a reduction in biological activities, loss of soil organic matter, and destroying soil structure (Bronick and Lal 2005; Zhao et al. 2016). Therefore, sustainable management with mixed cropping, cover crops, and rational fertilization has been widely accepted. No attention has been focused on the relationship between the bacterial community and enzymatic activity under conventional and sustainable management in the litchi orchards. Moreover, the temporal change in environmental factors shaping soil bacterial structure and enzymatic activity remains poorly understood. Thus, the two subjects were addressed that (i) which enzymatic activities can be affected by temporal changes and agricultural management practices; and (ii) which soil properties can mainly influence enzymatic activities and bacterial community. In this study, two litchi orchards under conventional and sustainable management were compared by determining the activities of different enzymes and soil bacterial communities in the time course. The crossover analysis can further examine how the soil enzymatic activity and bacterial composition alter under different agricultural management with temporal change.

\section{Materials and methods}

\section{Field site and soil chemical analyses}

The experimental field was located in the Taiwan Agricultural Research Institute, Council of Agriculture, Chiayi Agricultural Research Branch $\left(23^{\circ} 29^{\prime} 5.1288^{\prime \prime} \mathrm{N}, 120^{\circ} 28^{\prime}\right.$ $12.2592^{\prime \prime}$ E) (Additional file 1: Fig. S1). The litchi orchards (L. chinensis Sonn.) were managed by conventional (CA; $1.32 \mathrm{ha}$ ), and sustainable agriculture (SA; $1.33 \mathrm{ha})$ since 2006. The soils were classified as Hapludults according to the soil taxonomy of the United States Department of Agriculture. The litchi orchards performed by the conventional and sustainable agriculture had been planted for over 15 and 70 years, respectively. In the SA litchi orchard, no herbicide, pesticide, organic fertilizer, and chemical fertilizer were applied before 2007. Between 2007 and 2017, the soil was manually weeded without fertilizer application, and litchi had been slightly treated with herbicide in the SA. Moreover, litchi fruit was not harvested and dropped off naturally. CA soil was annually carried out with field irrigation, organic fertilizer, chemical fertilizer, herbicide, and pesticide. Additionally, the CA soil was also weeded, and the litchi tree was trimmed (Additional file 3: Table S1). The fruit in the CA litchi orchard was harvested from May to June every year. The temperatures and relative humidity at the sampling times, October 4, 2016 (CA1 and SA1), January 4, 2017 (CA2 and SA2), and April 11, 2017 (CA3 and SA3), were $29.8{ }^{\circ} \mathrm{C}, 23.5{ }^{\circ} \mathrm{C}, 29.9{ }^{\circ} \mathrm{C}$, and $72 \%, 70 \%$, and $53 \%$, 
respectively. The CA and SA soils respectively have three and five sampling sites because of the division of planting areas and road distinction. The surface soils (depth $0-10 \mathrm{~cm}$ ) from five plots of each sampling site were collected and pooled with replicate in sterile plastic tubes. To determine the enzymatic activity, the soil samples were directly brought back to the laboratory, sieved by using a 2-mm mesh, and homogenized by using a centrifugal ball mill (S100, Retsch, Hahn, Germany). The other soil samples stored at $-80^{\circ} \mathrm{C}$ were used for DNA extraction and chemical analysis. Soil suspension prepared in distilled water $(1: 1, \mathrm{w} / \mathrm{v})$ was used for testing $\mathrm{pH}$ and electrical conductivity. Organic matter was determined by a loss on the ignition after burning at $430{ }^{\circ} \mathrm{C}$ for $24 \mathrm{~h}$. The Kjeldahl method was used to measure total nitrogen. The soil extractable elements including $\mathrm{P}, \mathrm{K}, \mathrm{Ca}, \mathrm{Mg}, \mathrm{Fe}$, $\mathrm{Mn}, \mathrm{Cu}$, and $\mathrm{Zn}$ were determined by inductively coupled plasma (ICP) emission spectroscopy (Hendershot et al. 2008).

\section{Soil enzymatic activity}

$p$-Nitrophenyl phosphate, $p$-nitrophenyl sulfate, and $p$-nitrophenyl- $\beta$-D-glucopyranoside were respectively prepared as substrates for determining the enzymatic activities of acid phosphatase, arylsulfatase, and $\beta$-glucosidase (Eivazi and Tabatabai 1988; Ho 1979; Tabatabai and Bremner 1970). To measure the acid phosphatase, $0.5 \mathrm{~g}$ of soil was added into a mixture of $0.5 \mathrm{~mL}$ of $115 \mathrm{mM} p$-nitrophenyl phosphate, $0.2 \mathrm{~mL}$ of toluene, and $2 \mathrm{~mL}$ of modified universal buffer (MUB), and further incubated at $37^{\circ} \mathrm{C}$ for $1 \mathrm{~h}$. According to the Tabatabai method (Tabatabai 1982), MUB was manufactured including Tris, maleic acid, citric acid, boric acid, $\mathrm{NaOH}$, $\mathrm{HCl}$, and distilled water at $\mathrm{pH}$ 6.5. For arylsulfatase and $\beta$-glucosidase activity assay, the composition of the reaction was the same as that of acid phosphatase. Nevertheless, the substrate was replaced by $25 \mathrm{mM} p$-nitrophenyl sulfate and $25 \mathrm{mM} p$-nitrophenyl- $\beta$-D-glucopyranoside, respectively. These mixtures were incubated at $37^{\circ} \mathrm{C}$ for $1 \mathrm{~h}$. Then, $2 \mathrm{~mL}$ of $0.5 \mathrm{M} \mathrm{NaOH}$ and $0.5 \mathrm{~mL}$ of $0.5 \mathrm{M}$ $\mathrm{CaCl}_{2}$ were respectively added into the mixture to cease the enzymatic reaction of acid phosphatase and arylsulfatase. To terminate the $\beta$-glucosidase activity, $2 \mathrm{~mL}$ of $0.5 \mathrm{M}$ Tris buffer (pH 12) and $0.5 \mathrm{~mL}$ of $0.5 \mathrm{M} \mathrm{CaCl}_{2}$ were added. These mixtures were filtered by using filter paper (No. 393, Sartorius AG, Goettingen, Germany) and measured at $\mathrm{OD}_{400}$ by a spectrophotometer. Different concentrations of $p$-nitrophenol were utilized as the standard to calculate the enzymatic activity. Urease activity was determined according to Kandeler and Gerber (1988). One gram of soil was added into $0.5 \mathrm{~mL}$ of $0.08 \mathrm{M}$ urea and incubated at $37^{\circ} \mathrm{C}$ for $2 \mathrm{~h}$. Then, $10 \mathrm{~mL}$ of $1 \mathrm{~N}$ $\mathrm{KCl}$ was added into the mixture to stop the reaction and filtered (No. 393, Sartorius AG, Goettingen, Germany) to remove debris. The $400 \mu \mathrm{L}$ of $0.1 \%$ dichloroisocyanuric acid sodium salt, $1 \mathrm{~mL}$ of sodium salicylate (Na-salicylate $/ \mathrm{NaOH}$ ), and $1.8 \mathrm{~mL}$ of distilled water were mixed with $200 \mu \mathrm{L}$ filtrate, and further incubated in the dark for $30 \mathrm{~min}$. The reaction was determined at $\mathrm{OD}_{690}$ by using a spectrophotometer. Different concentrations of $\mathrm{NH}_{4} \mathrm{Cl}$ were utilized as the standard to calculate the enzymatic activity.

To measure the $\mathrm{N}_{2}$-fixing activity of soils, the acetylene reduction method was utilized (Hardy et al. 1973). An $80-\mathrm{mL}$ tube filled with $17 \mathrm{~mL}$ of soil and a $10 \%$ acetylene gas mixture was incubated at $25^{\circ} \mathrm{C}$ for $24 \mathrm{~h}$. A gas chromatography (GC) instrument (HITACHI model 163, Hitachi Ltd., Tokyo, Japan) equipped with a flame ionization detector (FID) and a packed column (1.0 m $\times 2.0 \mathrm{~mm}$ internal diameter, steel column packed with Porapak-T 80-100) was used to determine the ethylene catalyzed by soil nitrogenase. The GC parameters were as follows: carrier gas, nitrogen; flow rate, $35 \mathrm{~mL} \mathrm{~h}^{-1}$; FID temperature, $110^{\circ} \mathrm{C}$; and column temperature, $65^{\circ} \mathrm{C}$.

\section{Soil bacterial 16S rDNA amplicon sequencing by Illumina MiSeq and bioinformatic analysis}

The soil bacterial distribution was explored through soil DNA sequencing analysis using next-generation sequencing. The UltraClean Soil DNA Isolation Kit (MO BIO Laboratories, Inc., USA) with 1-g soil was used to extract soil DNA detected by a spectrophotometer at OD260/280 ratio in a range of $1.8-2.0$. The primers of $338 \mathrm{~F}\left(5^{\prime}-\mathrm{ACT}\right.$ CCTACGGGAGGCAGCAG-3 ${ }^{\prime}$ ) and 806R (5'-GGACTA CHVGGGTWTCTAAT-3') for the hypervariable V3-V4 region of the 16S rRNA were used for PCR (Caporaso et al. 2012; Lane 1991). The DNA sample using $30 \mathrm{ng}$ was amplified by PCR, containing 0.75 U PrimeSTAR HS DNA polymerase (Takara Bio, Japan), $1 \times$ PrimSTAR buffer, $0.2 \mathrm{mM}$ dNTPs, and $10 \mathrm{pM}$ forward and reverse primers. The PCR reaction was performed as follows: 3 min at $94{ }^{\circ} \mathrm{C}$ for 1 cycle, followed by 30 cycles of $30 \mathrm{~s}$ at $94{ }^{\circ} \mathrm{C}, 45 \mathrm{~s}$ at $55^{\circ} \mathrm{C}$ and $45 \mathrm{~s}$ at $72{ }^{\circ} \mathrm{C}$, and $10 \mathrm{~min}$ at $72{ }^{\circ} \mathrm{C}$ for 1 cycle. PCR products were blunted, and adapter ligation was conducted according to the Beijing Genomics Institute (BGI) experimental workflow (Ju et al. 2017; Li et al. 2020; Qin et al. 2012). Moreover, library construction, and amplicon sequencing were entrusted to the BGI (BGI, Shenzhen, China). The all standard protocols were described in the literature provided by BGI-Shenzhen ( $\mathrm{Li}$ et al. 2020; Qin et al. 2012). The quantification and qualification of the DNA library were detected by the Agilent 2100 bioanalyzer instrument (Santa Clara, CA, USA) and real-time quantitative PCR. The Illumina MiSeq platform $(2 \times 300$ bp paired-end reads $)$ was used for amplicon sequencing. 
The raw data were analyzed following the BGI bioinformatics workflow. The consensus sequence with the overlapped two paired-reads was generated by FLASH and merged to tags (Magoc and Salzberg 2011). The tags were clustered to operational taxonomic unit (OTU) with a $97 \%$ threshold by USEARCH and UPARSE (Edgar 2013). Chimeras were filtered out by using UCHIME and all tags were mapped to each OTU by using USEARCH GLOBAL (Edgar et al. 2011). The OTU representative sequence for the taxonomic ranks of microbes at $97 \%$ similarity was classified using the Ribosomal Database Project (RDP) classifier (Cole et al. 2014) and the Greengenes database (v201305) (DeSantis et al. 2006) was used to identify soil bacterial taxa. The Venn diagrams grouped the OTU representative sequence, the taxonomic distribution of microbes, and the redundancy analysis (RDA) of the relationship between the soil bacteria, enzymatic activities, and chemical properties were created by the R software (v3.1.1) (Foundation for Statistical Computing, Vienna, Austria). Alpha diversity indices including species observed (SOBS), Chao, ACE, Shannon, and Simpson were calculated by Mothur (v1.31.2). SOBS, Chao, and ACE can reflect the soil bacterial richness of community. The rarefaction curve could be used to estimate that the data is enough to cover all species in the soil community according to the three indices. Shannon and Simpson indicated the bacterial diversity of the community, affected by bacterial richness and evenness. These indices of calculation formula can refer to http://www.mothur.org/wiki/Calculators. The samples were grouped based on the sampling time and agricultural management for differential analysis of alpha diversity. The box plot of alpha diversity was drawn by the $R$ software. Beta diversity with weighted UniFrac was done by QIIME (v1.80). The heat map of beta diversity was generated by the package NMF of R software.

\section{Statistical analysis}

The variability among replicates was analyzed by the standard deviation (SD). Statistical significance at a confidence level of 95\% was measured through Duncan's multiple range test by using IBM SPSS Statistics v20 software package (SPSS Inc. Chicago, USA). Repeated measures analysis of variance (RM-ANOVA) was used to examine the interaction of temporal change and agricultural management affected by enzymatic activity, bacterial distribution, and alpha diversity. The RDA implemented in the vegan package of $\mathrm{R}$ software was used to analyze the relationship between the soil properties, enzymatic activities, bacterial distribution, and alpha diversity. The difference in soil enzymatic activities, soil bacteria, and soil properties was explored by ANOVA with multivariate linear regression. The responses of enzymatic activity and bacterial community to variance in soil properties were interpreted by the stepwise method (probability use of $\mathrm{F}<0.05$ ).

\section{Nucleotide sequence accession number}

This soil high-throughput DNA sequencing project was deposited at DDBJ/ENA/GenBank under accession numbers BioProject PRJNA609234 and BioSample SAMN14239000, SAMN14239003, SAMN14239006, SAMN14239008, SAMN14239071， SAMN14239231, SAMN14239232, SAMN14239233, SAMN14239279, SAMN14247548, SAMN14247549, SAMN14247570, SAMN14247586, SAMN14247633, SAMN14247636, SAMN14247637, SAMN14247688, SAMN14247698, SAMN14247701, SAMN14247707, SAMN14247714, SAMN14247780, SAMN14247782 and SAMN14247783.

\section{Results}

Soil properties in the litchi orchards

The soil samples of litchi orchards that were maintained under conventional (CA) and sustainable (SA) agriculture were collected trimester-wise successively from October 2016 and April 2017 to observe the impact of agricultural management and temporal change. The soil $\mathrm{pH}$ was ranged from 4.70 to 5.37 in the litchi orchards (Fig. 1). The pH of SA soil was slightly lower than that of CA soil. No obvious change between the EC values of CA and SA soils was observed in October 2016 and January 2017. However, a high soil EC value was detected in the CA soil of April 2017 due to the application of fertilizer in March 2017. The soil organic matter on average was $4.0 \%$ and $4.7 \%$ in the CA and SA soils, respectively, but there was no significant difference. The result of total nitrogen indicated that the content in the SA soil was slightly higher than in the CA soil. In addition, the total nitrogen was the highest in January 2017, reaching $1.8 \mathrm{mg} \mathrm{g}^{-1}$ soil in both soils. No significant difference was perceived between the CA and SA soils in the extractable elements including $\mathrm{Ca}, \mathrm{Mg}, \mathrm{Mn}$, and $\mathrm{Cu}$ (Table 1). The contents of $\mathrm{P}$ and $\mathrm{Zn}$ in the $\mathrm{CA}$ soil were higher than that in the SA soil. By contrast, the Fe trend was SA $>$ CA. Moreover, the extractable element of $\mathrm{K}$ was the highest in the CA soil of April 2017. According to the Pearson correlation analysis of soil properties, soil $\mathrm{pH}$ had a high relationship with the extractable elements (Additional file 4: Table S2). A positive correlation between organic matter and total nitrogen, and EC and potassium content was also documented.

\section{Soil enzymatic activities in the litchi orchards}

The soil enzymatic activities of acid phosphatase, arylsulfatase, $\beta$-glucosidase, urease, and $\mathrm{N}_{2}$-fixing activities involved in phosphorus, sulfur, carbon, and nitrogen 

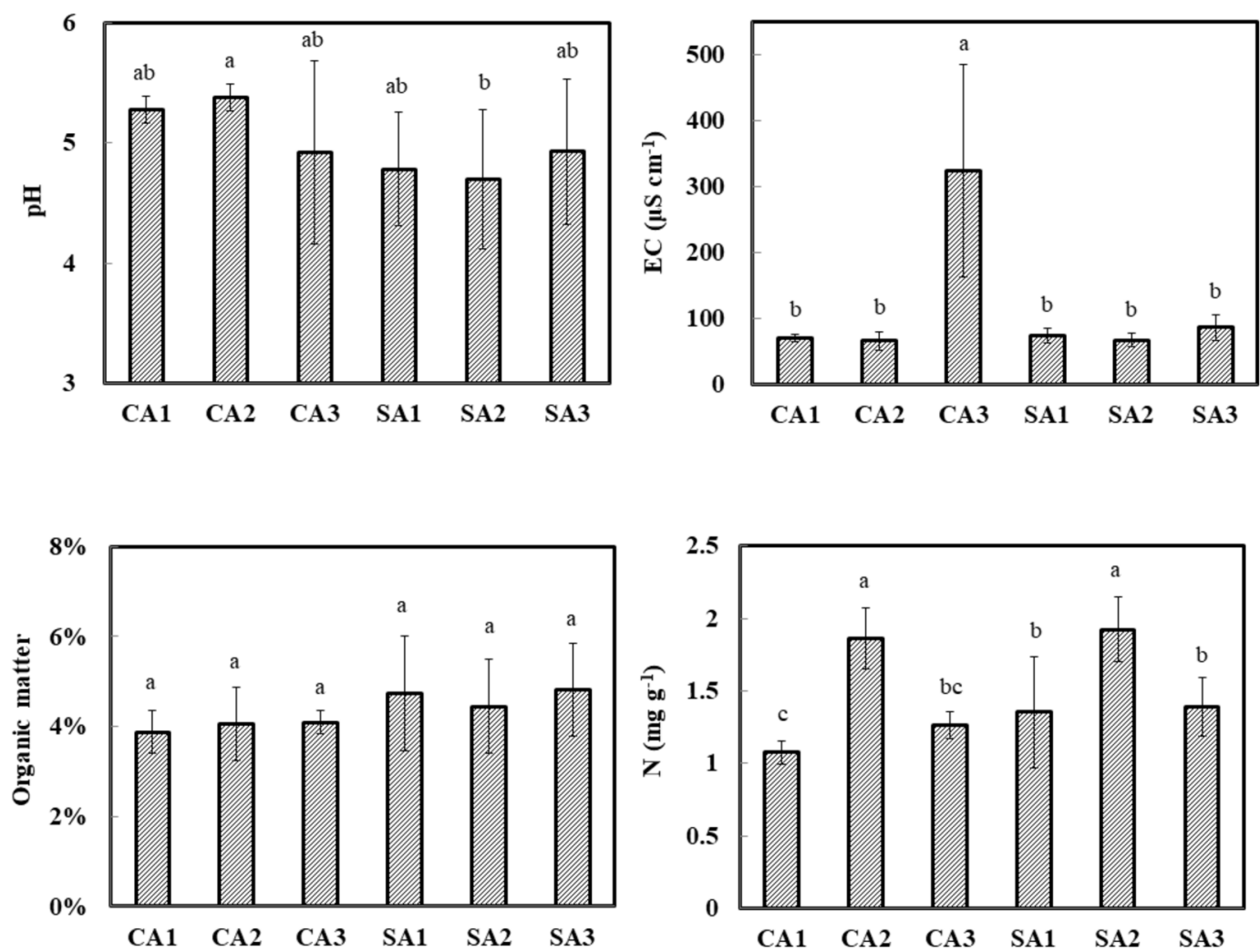

Fig. 1 Temporal variations in the soil pH, EC, total nitrogen, and organic matter of litchi orchards that were maintained under conventional (CA) and sustainable (SA) agricultural practices. 1, 2 and 3 indicate successive trimester samplings carried out on October 2016, January 2017 and April 2017, respectively. Results are shown as mean \pm standard deviation. The different letters labeled at columns are significantly different according to Duncan's test $(p<0.05)$ by IBM SPSS Statistics v20

Table 1 Temporal variations in the soil extractable elements of litchi orchards that were maintained under conventional (CA) and sustainable (SA) agricultural practices

\begin{tabular}{|c|c|c|c|c|c|c|c|c|}
\hline \multirow[t]{3}{*}{ Soils } & \multicolumn{8}{|l|}{ Elements } \\
\hline & 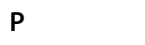 & $\mathrm{K}$ & $\mathrm{Ca}$ & $\mathrm{Mg}$ & $\mathrm{Fe}$ & $M n$ & $\mathrm{Cu}$ & $\mathrm{Zn}$ \\
\hline & \multicolumn{8}{|c|}{$\mathrm{mg} \mathrm{kg}^{-1}$ soil } \\
\hline CA1 & $2.3 \pm 1.0^{b c}$ & $211.0 \pm 54.7^{b}$ & $583.3 \pm 143.1^{\mathrm{a}}$ & $160.3 \pm 18.5^{a}$ & $453.3 \pm 79.0^{a}$ & $104.3 \pm 47.5^{a}$ & $4.0 \pm 2.1^{\mathrm{a}}$ & $3.5 \pm 0.5^{b}$ \\
\hline SA1 & $1.9 \pm 0.7^{c}$ & $145.1 \pm 52.3^{b}$ & $703.5 \pm 371.1^{\mathrm{a}}$ & $195.9 \pm 70.5^{\mathrm{a}}$ & $428.1 \pm 15.3^{\mathrm{ab}}$ & $114.5 \pm 38.1^{\mathrm{a}}$ & $2.9 \pm 1.5^{\mathrm{a}}$ & $4.0 \pm 1.3^{b}$ \\
\hline CA2 & $4.3 \pm 1.2^{\mathrm{ab}}$ & $251.3 \pm 88.2^{b}$ & $882.6 \pm 292.8^{a}$ & $174.1 \pm 29.9^{\mathrm{a}}$ & $419.2 \pm 59.7^{\mathrm{ab}}$ & $77.0 \pm 42.5^{\mathrm{a}}$ & $5.7 \pm 1.8^{\mathrm{a}}$ & $7.0 \pm 1.0^{\mathrm{a}}$ \\
\hline SA2 & $3.4 \pm 1.2^{\mathrm{abc}}$ & $139.0 \pm 47.1^{b}$ & $614.9 \pm 371.0^{\mathrm{a}}$ & $160.7 \pm 73.3^{a}$ & $471.1 \pm 21.1^{\mathrm{a}}$ & $73.0 \pm 22.8^{\mathrm{a}}$ & $4.3 \pm 1.9^{a}$ & $4.9 \pm 2.2^{\mathrm{ab}}$ \\
\hline CA3 & $4.7 \pm 1.5^{\mathrm{a}}$ & $543.0 \pm 504.3^{\mathrm{a}}$ & $911.5 \pm 411.2^{\mathrm{a}}$ & $149.5 \pm 16.7^{\mathrm{a}}$ & $378.2 \pm 64.6^{b}$ & $84.2 \pm 22.5^{\mathrm{a}}$ & $5.1 \pm 1.9^{\mathrm{a}}$ & $7.0 \pm 0.7^{\mathrm{a}}$ \\
\hline SA3 & $4.0 \pm 1.7^{\mathrm{ab}}$ & $138.3 \pm 39.6^{b}$ & $633.3 \pm 387.9^{\mathrm{a}}$ & $144.6 \pm 67.5^{a}$ & $420.5 \pm 10.7^{\mathrm{ab}}$ & $99.5 \pm 47.8^{\mathrm{a}}$ & $4.4 \pm 2.2^{\mathrm{a}}$ & $5.5 \pm 2.4^{\mathrm{ab}}$ \\
\hline
\end{tabular}

1,2 and 3 indicate successive trimester samplings carried out on October 2016, January 2017 and April 2017, respectively. The extractable elements including P, K, Ca, $\mathrm{Mg}, \mathrm{Fe}, \mathrm{Mn}, \mathrm{Cu}$, and $\mathrm{Zn}$ were determined by inductively coupled plasma emission spectroscopy. Results are shown as mean \pm standard deviation

cycles were measured (Fig. 2). The result revealed that the enzymatic activities were affected not only by agricultural management but also temporal changes. Acid phosphatase and arylsulfatase in the SA soil had higher activity than in the CA soils. The enzymatic activity of arylsulfatase dropped in April 2017. By contrast, $\beta$-glucosidase and urease activities in the CA soil were higher than in the SA soils. Urease activity tended to be high in January 2017. The $\mathrm{N}_{2}$-fixing activity in soils was performed by the acetylene reduction assay. The result 

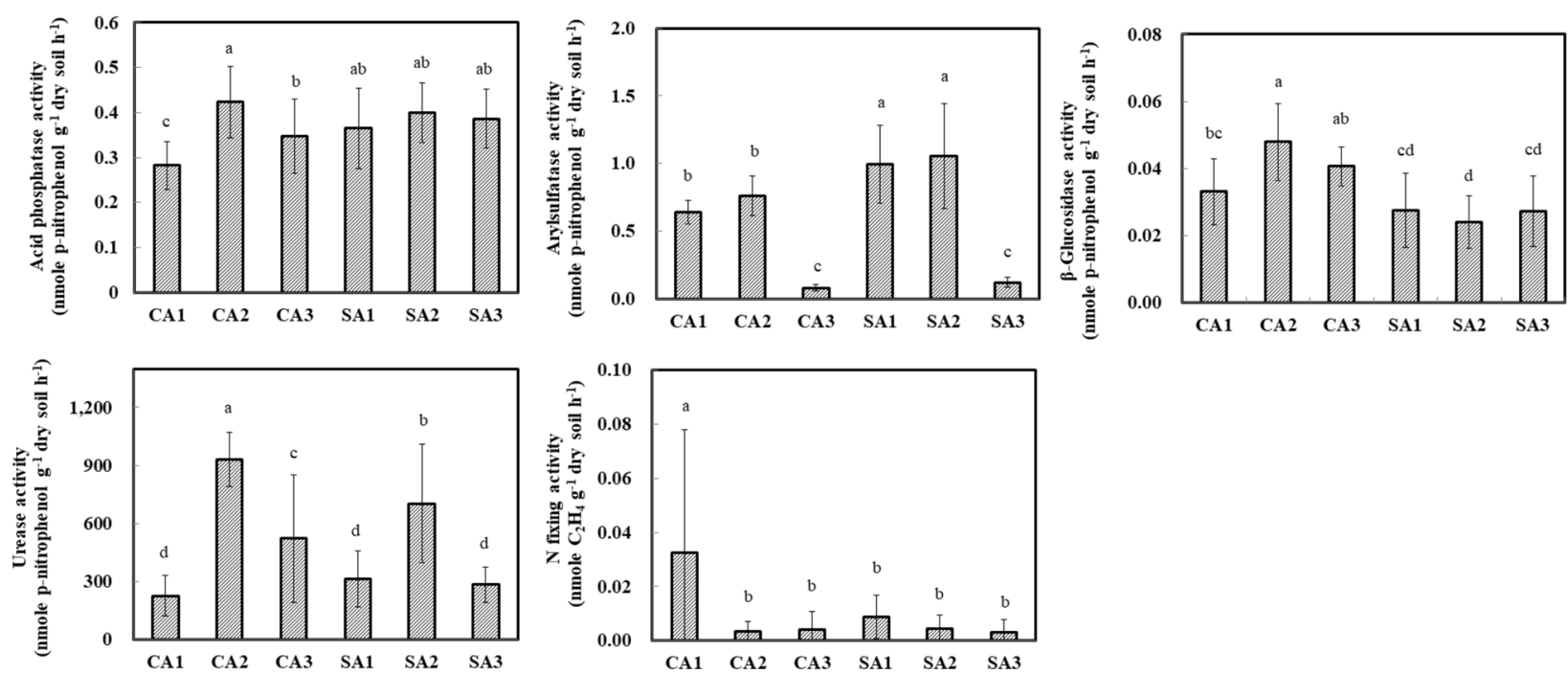

Fig. 2 Temporal variations in the soil enzymatic activities of litchi orchards that were maintained under conventional (CA) and sustainable (SA) agricultural practices. 1, 2 and 3 indicate successive trimester samplings carried out on October 2016, January 2017 and April 2017, respectively. Acid phosphatase, arylsulfatase, and $\beta$-glucosidase activities were analyzed by the $p$-nitrophenol method. The $\mathrm{N}_{2}$-fixing activity was detected by the acetylene reduction method using gas chromatography. Results are shown as mean \pm standard deviation. The different letters labeled at columns are significantly different according to Duncan's test $(P<0.05)$ by IBM SPSS Statistics v20

indicated that the $\mathrm{N}_{2}$-fixing activity in the CA soil of October 2016 was higher than that of the other soils. No significant difference was observed in the CA and SA soils of January 2017 and April 2017.

RM-ANOVA was used to assess the effect of agricultural management on different enzymatic activity across temporal change (Table 2). The result indicated significant variations in enzymatic activity with sampling time. However, a significant interaction between temporal change and agricultural management only appeared in the arylsulfatase, $\beta$-glucosidase, and urease activities.

\section{Soil bacterial community through $16 \mathrm{~S}$ rRNA analysis using Illumina MiSeq}

To analyze the diversity of the bacterial community with the soil samples, the high-throughput sequencing was used for the hypervariable V6 region of the 16S rRNA by Illumina MiSEq. Raw reads with adapter contamination, ambiguous base, and low complexity were trimmed and removed. The average clean paired-reads and data were 54,526 reads and $31.176 \mathrm{Mb}$ in each sample, respectively (Additional file 5: Table S3). Venn diagram represented the common and unique OTUs of CA and SA soil samples (Additional file 2: Fig. S2). The number of unique OTUs in CA and SA soils was obviously low in January

Table 2 Significance of $p$-value for repeated measures ANOVA on acid phosphatase, arylsulfatase, $\beta$-glucosidase, urease, and $N_{2}$-fixing activity from the litchi orchard soils

\begin{tabular}{|c|c|c|c|c|c|c|c|c|c|c|}
\hline \multirow[t]{3}{*}{ Model term } & \multicolumn{10}{|c|}{ Enzymatic activity } \\
\hline & \multicolumn{2}{|c|}{ Acid phosphatase } & \multicolumn{2}{|c|}{ Arylsulfatase } & \multicolumn{2}{|c|}{$\beta$-Glucosidase } & \multicolumn{2}{|l|}{ Urease } & \multicolumn{2}{|c|}{$\mathrm{N}_{2}$-fixing } \\
\hline & $F$ & $P$ & $F$ & $P$ & $F$ & $P$ & $F$ & $P$ & $F$ & $P$ \\
\hline \multicolumn{11}{|c|}{ Test of within-subjects effects } \\
\hline Time & 7.785 & $0.001 * *$ & 111.941 & $<0.001 * *$ & 7.130 & $0.004^{* *}$ & 34.217 & $<0.001^{* *}$ & 7.596 & $0.009 * *$ \\
\hline Time $\times$ Management & 2.835 & 0.069 & 3.918 & $0.027^{*}$ & 18.992 & $<0.001^{* *}$ & 3.586 & $0.047^{*}$ & 3.774 & 0.060 \\
\hline \multicolumn{11}{|c|}{ Test of between-subjects effects } \\
\hline Intercept & 1725.628 & $<0.001^{* *}$ & 310.086 & $<0.001^{* *}$ & 324.388 & $<0.001^{* *}$ & 738.748 & $<0.001^{* *}$ & 20.710 & $<0.001 * *$ \\
\hline Management & 3.433 & 0.077 & 10.950 & $0.003^{* *}$ & 14.856 & $0.001^{* *}$ & 12.037 & $0.002^{* *}$ & 3.692 & 0.068 \\
\hline
\end{tabular}

Significance is indicated by ** $p$-value $<0.01$, and ${ }^{*} p$-value $<0.05$ 
2017. In addition, the unique OTUs in the SA soil were considerably higher than those of the CA soil in October 2016 and January 2017.

The bacterial distribution in the soils was analyzed against the Greengenes database. The result revealed that Acidobacteria, Actinobacteria, Bacteroidetes, Chloroflexi, and Proteobacteria were the predominant phyla (Fig. 3). No significant difference was observed in the Actinobacteria and Chloroflexi between the CA and SA soils. The Acidobacteria in the SA soil was higher than that of CA soil. However, Bacteroidetes and Proteobacteria in the CA soil had a higher amount than that of SA soil. Moreover, the relative abundance of Acidobacteria, Bacteroidetes, and Proteobacteria was considerably influenced by sampling time. Relative abundance of Acidobacteria in the CA and SA soils was high in April 2017 than in October 2016 and January 2017, whereas the lower proportion of Proteobacteria was detected in April 2017. Additionally, the relative abundance of Bacteroidetes in October 2016 was 5.1- and 2.4-fold higher than that in January 2017 and April 2017, respectively. Further taxonomic division at the class-level indicated that Gammaproteobacteria was the most dominant with a relative abundance of $17.1 \%$ and $14.3 \%$ in the CA and SA soils on average, respectively.

The observed species (SOBS) and alpha-diversity including Chao, ACE, Shannon, and Simpson were evaluated under the impact of agricultural management and temporal change (Fig. 4). SOBS, Chao, and ACE represent the species richness of community. The averages of SOBS, Chao, and ACE were 2259.22, 2795.26, and 2833.53 in the CA soil, and 1799.67, 2243.00, and 2248.71 in the SA soil. The result revealed that the CA soil had a higher amount of bacterial species and greater richness than that of SA soil. Nevertheless, the bacterial diversity was variable at different sampling time. The trend of bacterial diversity in both soils was following the order April $2017>$ October 2016 > January 2017 according to the analysis of Shannon and Simpson indices. Beta-diversity with weighted UniFrac analysis was used to estimate the differences of soil samples in species complexity (Fig. 5). The result indicated that the five clusters can be divided, suggesting that the temporal changes distinguished from the soil samples in addition to the treatment of agricultural management.

Repeated measures analysis of variances (ANOVAs) was used to evaluate the effect of agricultural management on the bacterial predominant phyla and alpha diversity across temporal change (Additional file 6: Table S4). The result indicated that a significant difference with temporal change was observed in Acidobacteria and Proteobacteria. A marginally significant temporal change was apparent in Bacteroidetes. However, no significant agricultural management effect that differed over temporal change was perceived in these predominant phyla. On the other hand, no significant difference with time and agricultural management was found in the SOBS, Chao, and ACE index corresponding to bacterial richness (Additional file 7: Table S5). Nevertheless, a significant difference with time appeared in the Shannon and Simpson index corresponding to bacterial diversity.

\section{Relationship between the bacterial community, soil enzymatic activity, and soil properties}

The relationship between bacterial community, enzymatic activity, and soil properties was further explored
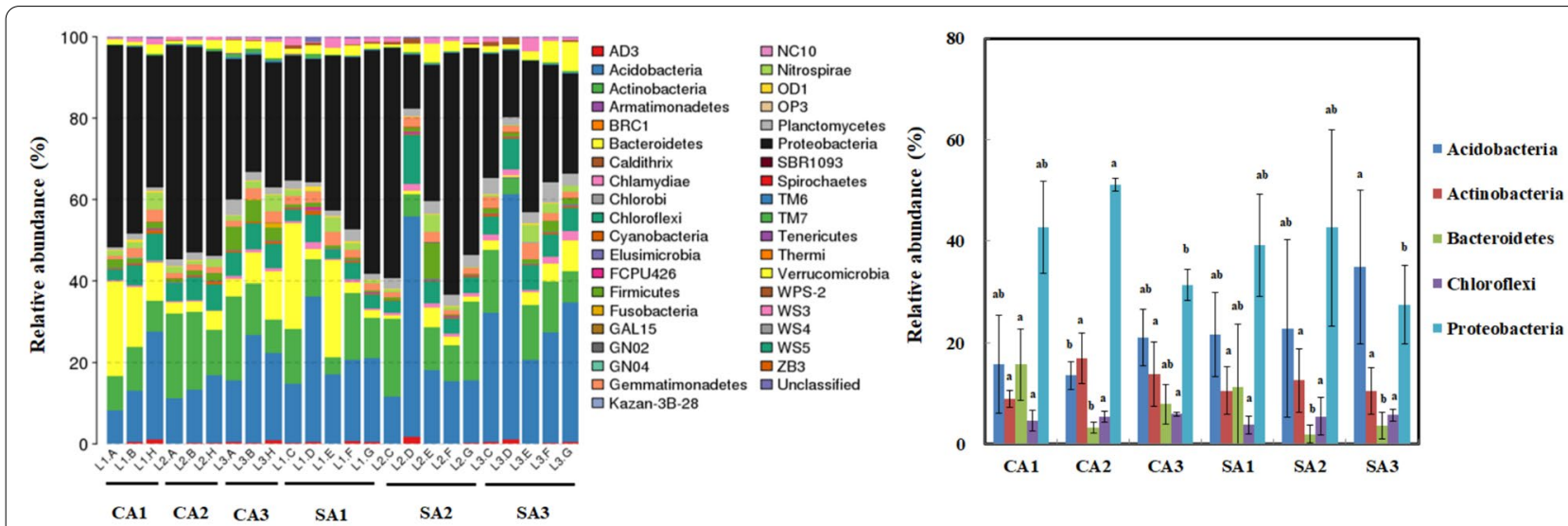

Fig. 3 Temporal variation in the Phylum-level distribution of OTUs in the soil samples of litchi orchards that were maintained under conventional (CA) and sustainable (SA) agricultural practices. 1, 2 and 3 indicate successive trimester samplings carried out on October 2016, January 2017 and April 2017, respectively. Graph showing the taxonomic composition distribution was generated by the R software. The dominant phyla including Acidobacteria, Actinobacteria, Bacteroidetes, Chloroflexi, and Proteobacteria were further compared. Results are shown as mean \pm standard deviation 

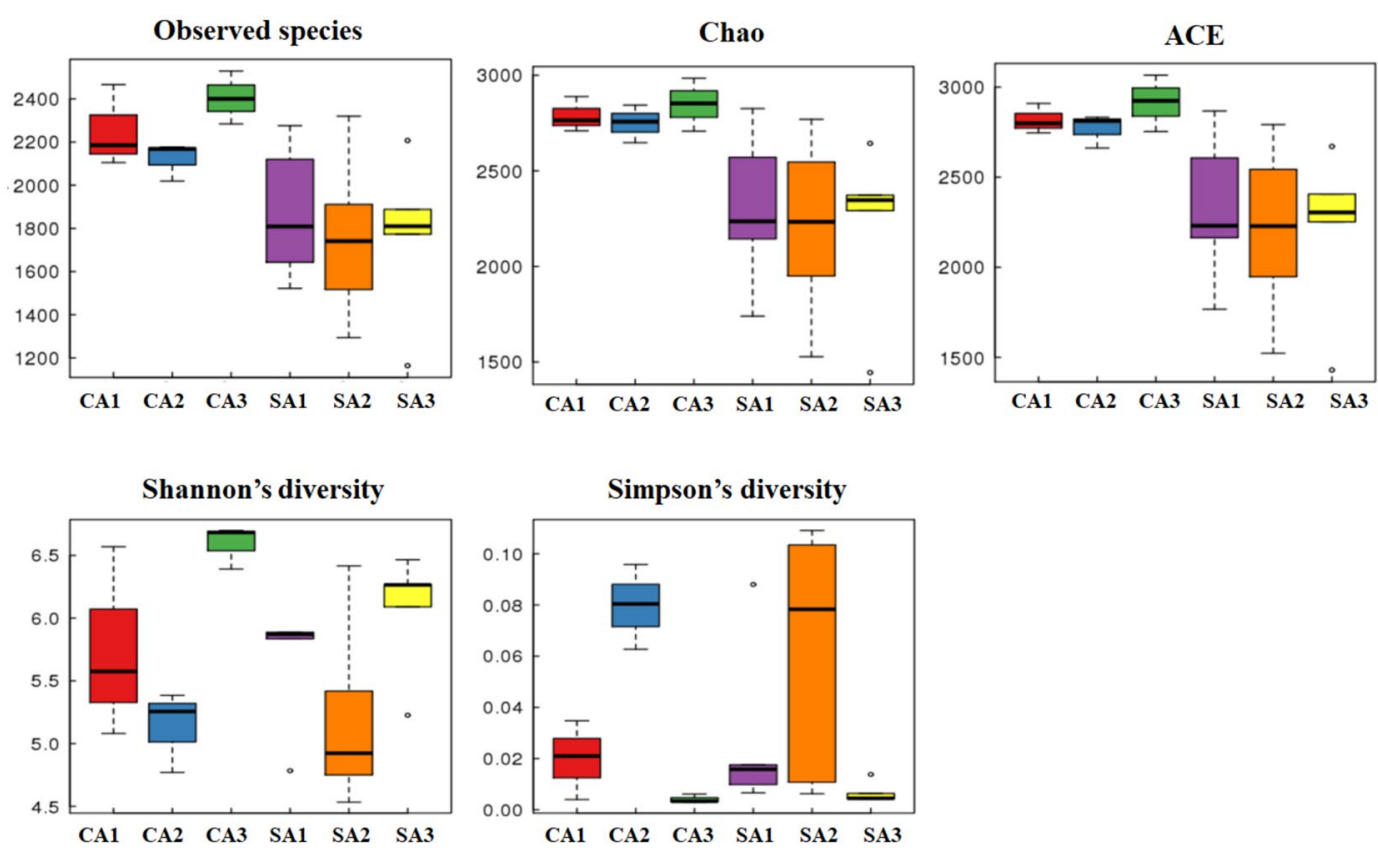

Fig. 4 Temporal variations in the alpha diversity indices of soil bacteria inhabiting the litchi orchards that were maintained under conventional (CA) and sustainable (SA) agricultural practices. 1, 2 and 3 indicate successive trimester samplings carried out on October 2016, January 2017 and April 2017, respectively. The indices were calculated by Mothur (v1.31.2) and graphs were generated by the R software

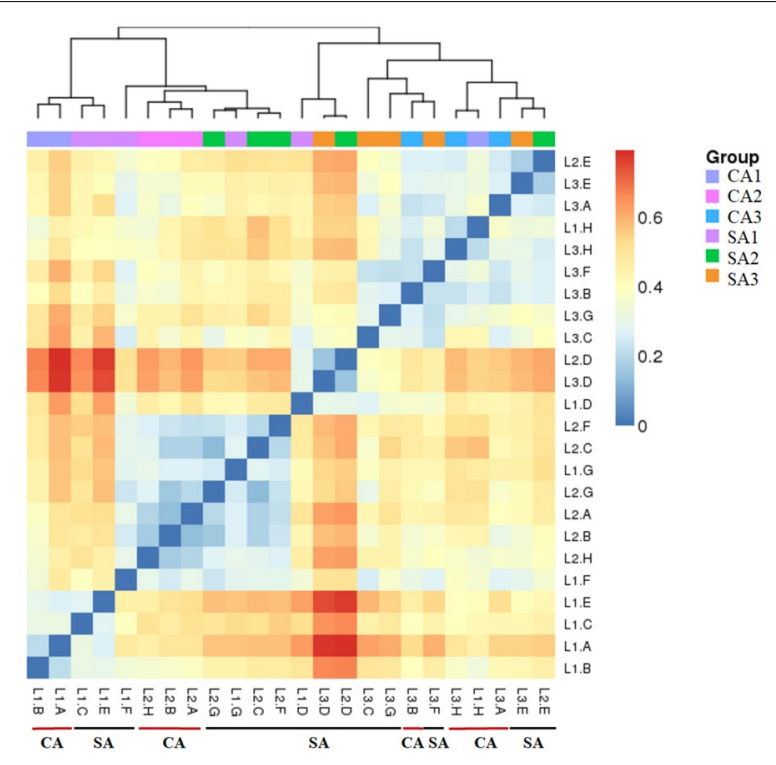

Fig. 5 Temporal variations in the beta diversity of the soil bacteria inhabiting litchi orchards that were maintained under conventional (CA) and sustainable (SA) agricultural practices. 1, 2 and 3 indicate successive trimester samplings carried out on October 2016, January 2017 and April 2017, respectively. Beta diversity with weighted UniFrac analysis between October 2016 and April 2017 was measured by software QIIME (v1.80). Beta diversity heat map was generated by the R software in the NMF package by redundancy analysis (Fig. 6). The RDA components interpreted $68.68 \%, 93.33 \%$, and $99.26 \%$ of the variation in enzymatic activity, bacterial community, and diversity, respectively. Concerning the enzymatic activity, the first component explained $41.36 \%$ of the total variation (Fig. 6A). Soil samples were clustered along the sampling time. Acid phosphatase, $\beta$-glucosidase, and urease activities were related to total nitrogen in the soils of January 2017, whereas arylsulfatase activity occurred predominantly in the SA soil of October 2016 and January 2017 and negatively correlated with EC. Moreover, $\beta$-glucosidase was associated with the available phosphorus. Regarding the dominant phyla of bacteria, clustering between soil samples was not obvious (Fig. 6B). A related correlation was found in EC and available potassium with the abundance of Proteobacteria. However, the relationship of the other dominant bacteria, such as Acidobacteria, Actinobacteria, and Chloroflexi, and soil $\mathrm{EC}$, and available potassium was the opposite. A similar result of the negative association was also observed between Bacteroidetes, and soil organic matter and available phosphorus. SOBS, Chao, and ACE indices were predominated in the CA soils and positively associated with soil pH (Fig. 6C). In addition, a positive correlation between bacteria diversity such as Shannon index, and soil EC and organic matter was dominantly perceived in the soils of October 2016 and April 2017. 

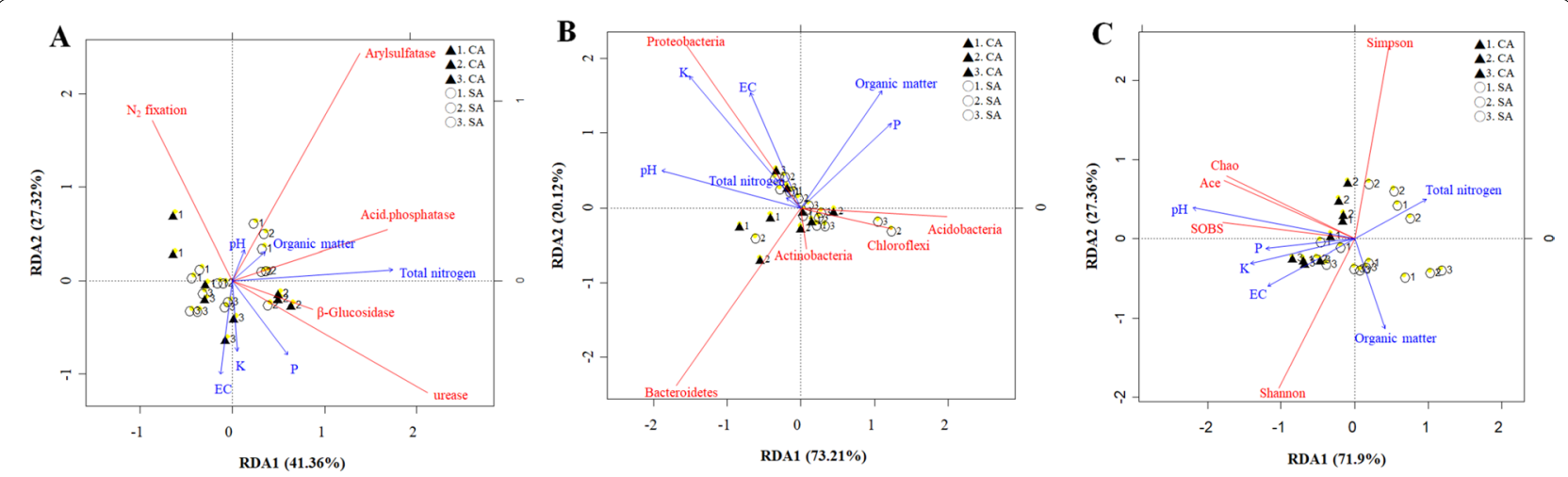

Fig. 6 Redundancy analysis of the temporal variation in the soil characteristics of litchi orchards that were maintained under conventional (CA) and sustainable (SA) agricultural practices. 1, 2 and 3 indicate successive trimester samplings carried out on October 2016, January 2017 and April 2017, respectively. The comparison between the soil properties ( $\mathrm{pH}, \mathrm{EC}, \mathrm{K}$, total $\mathrm{N}$, and $\mathrm{OM}$ ), and $\mathbf{A}$ enzymatic activities, $\mathbf{B}$ the most abundant bacterial phyla, and $\mathbf{C}$ alpha diversity of OTUs was done by RDA. The RDA plots were generated by the R software in the vegan package

Multivariate linear regression ANOVA with stepwise method was used to model the relationship between the enzymatic activity, bacterial community and soil properties. Pearson correlation was developed and shown (Table 3 and Additional file 8: Table S6). No significant association with soil property was observed in the $\mathrm{N}_{2}$-fixing activity and the dominant bacteria including Acidobacteria, Actinobacteria, Bacteroidetes, and Chloroflexi. In addition, under $\mathrm{p}$-value $<0.05$, acid phosphatase, arylsulfatase, $\beta$-glucosidase, SOBS, Chao, ACE, Shannon, and Simpson were used as the dependent variable in the multivariate linear regression with stepwise method. Equations were shown in Additional file 9: Table S7. On the other hand, the soil enzymatic activities were used as the dependent variable, and the dominant bacterial phyla were used as the independent variable in the stepwise multiple regression model. Under $\mathrm{p}$-value $<0.05$, only $\mathrm{N}_{2}$-fixing was a significant difference with the dominant bacteria (Additional file 9: Table S7).

\section{Discussion}

Temporal variation including climate conditions and soil properties is relatively common in different ecosystems with seasonal changes (Buscardo et al. 2018; Shigyo et al. 2019). Several kinds of research indicated that the observed species abundance and diversity of soil bacteria revealed the various patterns in the seasonal dynamics (Armstrong et al. 2016; Kivlin and Hawkes 2016; Murphy et al. 2016; Park et al. 2015; Shigyo et al. 2019). However, little attention has been done regarding the relationship between the soil bacterial community and enzymatic activity with the temporal changes under different agricultural practices. In this study, the soil bacterial community and enzymatic activity mediated by conventional and sustainable management in the litchi orchards were compared and determined. The litchi orchard in the SA soil has been planted for over 70 years without the application of pesticide, organic fertilizer, and chemical fertilizer. Because there has been no man-made interference for a long time, the SA soil was similar to the forest soil with a low $\mathrm{pH}$ through biological acidification or air pollution (Mao et al. 2017; Tamm and Hallbäcken 1986). The EC value fluctuated with fertilization in the $\mathrm{CA}$ soil whereas it was stable in the SA soil (Fig. 1). Moreover, the SA soil with old-growth litchi was typically rich in nitrogen, but poor in extractable phosphorus through soil leaching and immobilizing process (Vitousek et al. 2010). Although no fertilizer was applied in the SA soil, organic matter in the

Table 3 Pearson correlation between enzymatic activity and bacterial community

\begin{tabular}{llllll}
\hline & Acidobacteria & Actinobacteria & Bacteroidetes & Chloroflexi & Proteobacteria \\
\hline Acid phosphatase & 0.168 & 0.049 & -0.135 & 0.200 & -0.184 \\
Arylsulfatase & -0.286 & 0.103 & 0.106 & -0.059 & $\mathbf{0 . 3 6 9 ^ { * }}$ \\
$\beta$-Glucosidase & -0.147 & -0.181 & 0.053 & 0.001 & 0.142 \\
Urease & 0.048 & $-\mathbf{0 . 3 8 2 ^ { * }}$ & 0.263 & -0.079 & -0.075 \\
N-fixing & -0.311 & -0.135 & $\mathbf{0 . 4 2 5 ^ { * }}$ & -0.135 & 0.300
\end{tabular}

Significance is indicated by * $p$-value $<0.05$ 
SA soil was equal to or slightly higher than that in the CA soil. This may result from a lot of litter and fruit decomposition residue. These soil properties indicated that long-term litchi cultivation resulted in a lowering of $\mathrm{pH}$ and reducing the available elements such as phosphorus in the soils. Similarly, the positive correlation between $\mathrm{pH}$ and available phosphorus was observed in the forest soil (Yang et al. 2018). Forest trees had a high influence on soil than that of perennial vegetation because of their longevity without soil management.

In the present study, different enzymatic activities revealed the various patterns depending on the sampling times and agricultural managements (Fig. 2). The patterns of RDA analysis did not synchronize between the enzymatic activities and bacterial community. The cluster among enzymatic activities, soil properties, and agricultural management practices was clearly distinguished (Fig. 6). According to the repeated measures ANOVA analysis, acid phosphatase, arylsulfatase, $\beta$-glucosidase, urease, and $\mathrm{N}_{2}$-fixing activity were all significantly affected by the temporal change (Table 2). Nevertheless, only arylsulfatase, $\beta$-glucosidase, and urease were significantly responded in the interaction of time and treatment. Although $\beta$-glucosidase is known to participate in the carbon cycle and associated with organic carbon (Dai et al. 2018; Xian et al. 2015), soil pH and phosphorus content were the dominant factors involved in the $\beta$-glucosidase activity in this study. According to the stepwise multiple regression model, the phosphorus explained $39 \%$ of the variation in the $\beta$-glucosidase activity (Additional file 9: Table S7, Eq. 1). Fatemi et al. indicated that the soil $\beta$-glucosidase activity was elevated in response to acute nutrient additions with phosphorus amendment, suggesting that inorganic phosphorus was important in regulating the soil $\beta$-glucosidase in the acid forest soils (Fatemi et al. 2016). Besides, phosphorus was deficient in acidic soil and complexed with iron and aluminum (Chen et al. 2006). Therefore, the soil $\beta$-glucosidase was positively associated with soil $\mathrm{pH}$ and phosphorus in the litchi orchards. The acid phosphatase and urease activities involved in mineralization of organic phosphorus and urea hydrolysis were related to the total nitrogen in the CA and SA soils of January 2017 by the RDA analysis. Under the probability of $\mathrm{F}<0.05$, the multiple regression model picked out total nitrogen as a significant predictor of acid phosphatase for describing $29.5 \%$ of the variation (Additional file 9: Table S7, Eq. 2). This result was consistent with the different soil environments such as the coastal saline soil, indicating the close relationship between soil nitrogen content and enzymatic activity (Xie et al. 2017). In addition, the increase of diazotrophs abundance was probably associated with raising the activity of acid phosphatase and urease, requiring a considerable amount of nitrogen (Lemanowicz 2011; Xie et al. 2017). However, $\mathrm{N}_{2}$-fixing activity across temporal change was not coincident with the activity of acid phosphatase and urease in this study. This finding was similar to some studies which have shown that high nitrogen levels did not affect nitrogen fixation activity and the abundance of diazotrophic communities instead (Barron et al. 2008; Matson et al. 2015). Hence, the association of these enzymatic activities is worthy of further investigation.

Arylsulfatase can catalyze the hydrolysis of various substrates attached to the free sulfate group (Pettit et al. 1977). A positive relationship between the total nitrogen and arylsulfatase activity was observed in the SA soils (Additional file 9: Table S7, Eq. 3). However, the arylsulfatase activity was significantly dropped in the CA and SA soils of April 2017. Also, the atmospheric relative humidity and Proteobacteria relative abundance at sampling time were respectively declined in April 2017. This may be due to climatic effect on soil microorganisms (Mandal and Neenu 2012). It was generally believed that the climate change of temperature contributing to global warming was an important determinant for the regulation of soil biological structure and function. Nevertheless, the relative humidity related to water vapor can directly influence infrared radiation and indirectly change atmospheric temperature (Tullus et al. 2012). In this study, the relationship among the relative humidity, temperature, bacterial community and enzymatic activity could be explored by the Pearson correlation (Additional file 10: Table S8 and Additional file 11: Table S9). The result indicated that the temperature had a significantly positive correlation with the Shannon and Simpson index. By contrast, the relative humidity had a significantly negative correlation with the Shannon and Simpson index. On the other hand, the temperature had a significantly negative correlation with the acid phosphatase, arylsulfatase and urease. Nevertheless, the relative humidity had a significantly positive correlation with the arylsulfatase. Thus, the relative humidity and temperature could alter soil bacterial community and enzymatic activity.

Concerning the bacterial community, the dominant phyla were spatially stable but varied depending on temporal change such as Acidobacteria and Proteobacteria by the repeated measures ANOVA analysis (Additional file 6: Table S4). Although the in-depth analysis of orchard soil in Taiwan was relatively rare, the dominant phyla of litchi soil was consistent with montane forest ecosystem in Taiwan (Lin et al. 2010). In addition, no significant difference under different agricultural management across time was observed in the bacterial richness such as the SOBS, Chao, and ACE index (Additional 
file 7: Table S5). However, the bacterial diversity, Shannon and Simpson index, was significantly influenced by temporal change but not by agricultural management. Our results were significantly different from the analysis of neotropical rainfall and desert soil (Armstrong et al. 2016; Kivlin and Hawkes 2016). In the neotropical rainfall soil, a significant interaction between temporal change and vegetation type was perceived in bacterial richness and diversity (Kivlin and Hawkes 2016). By contrast, bacterial richness was spatially more variable than that of temporal variability in the desert soil (Armstrong et al. 2016). This suggested that the different environmental soil had different consequences on the bacterial structure. Additionally, the bacterial diversity, calculated by the Shannon and Simpson index, was lower in January 2017 than the other sampling times. January 2017 was the lowest temperature recorded in all sampling times. This suggested that the seasonal effect with temperature change obviously affected the soil bacterial diversity. However, our result was contrary to the results of the previous studies, indicating low bacterial richness and diversity in the summer (Jung et al. 2012; Rasche et al. 2011).

Taking together our results imply that the enzymatic activity was more sensitive to temporal change and agricultural management than that of bacterial richness and diversity. Several environmental factors such as climate change, soil organic matter, $\mathrm{pH}$, and water-soluble ions can examine the temporal change of the microbial community (Armstrong et al. 2016; Kivlin and Hawkes 2016; Shigyo et al. 2019). According to the Pearson correlation and RDA between bacterial richness and soil properties, soil $\mathrm{pH}$ and extractable potassium were significantly affect the SOBS, ACE, and Chao index in the present study (Additional file 8: Table S6) (Fig. 6). Soil pH was considered to be the main factor that impacting the bacterial community (Lammel et al. 2018; Lauber et al. 2009; Shen et al. 2019). This phenomenon was often found in the acidity forest soil due to the leaching, organic matter decay and acidic parent material. Moreover, potassium is the primary prerequisite for an organism's growth because it is involved in a regulator of cytoplasmic $\mathrm{pH}$ and cell turgor (Booth 1985). A similar result was also observed in the Shigyo et al. study, indicating that the shape of the microbial community was influenced by water-soluble potassium and phosphorus (Shigyo et al. 2019). Further modeling the soil bacterial community and property by multivariate linear regression ANOVA with the stepwise method can find the possible correlation and variance. No significant relationship was perceived in the dominant bacteria such as Acidobacteria, Actinobacteria, Bacteroidetes, Chloroflexi, and Proteobacteria under the probability of $\mathrm{F}<0.05$. Nevertheless, among the six quantified soil properties, the multiple regression model picked out $\mathrm{pH}$ and $\mathrm{EC}$ as the significant predictor of SOBS, Chao, ACE, and Shannon. Because the old-growth litchi in the SA has resulted in biological acidification with a low $\mathrm{pH}$ of the soil and was similar to the forest soil, it was an inverse effect on plants with the deficiency of nutrients such as phosphorus (Mao et al. 2017; Tamm and Hallbäcken 1986). In this study, the soil $\mathrm{pH}$ and $\mathrm{EC}$ as the significant predictors explained $76.9 \%$ and $33.8 \%$ of the variation in the SOBS and Shannon index, respectively (Additional file 9: Table S7, Eqs. 4-5). In addition to soil $\mathrm{pH}$ and $\mathrm{EC}$, it also contained phosphorus content, which can explain $77.1 \%$ and $79 \%$ of the variation in the Chao and ACE index (Additional file 9: Table S7, Eqs. 6-7). On the other hand, the Simpson index represents the probability that two randomly selected individuals belong to different species, indicating the bigger the value, the lower diversity (McCune and Grace 2002). The multiple regression model picked out organic matter and total nitrogen as the significant predictors of Simpson instead (Additional file 9: Table S7, Eq. 8). Because no ideal diversity index was suggested (Morris et al. 2014), SOBS, Chao, ACE, and Shannon may appear interchangeable by the multiple regression model and were preferable. Furthermore, a significant association was observed between soil enzymatic activity and dominant phyla. The multiple regression model picked out $\mathrm{N}_{2}$-fixing activity as a significant predictor of Bacteroidetes for explaining $18 \%$ of the variation. In the Bacteroidetes, the $\mathrm{N}_{2}$-fixing bacteria revealed the presence of Flavobacterium in this study, which may be contributed by a nitrogen-fixing bacterium, Flavobacterium nitrogenifigens (Kampfer et al. 2015). This result of crossover analysis could explore the association of soil enzymatic activity with bacterial composition in the soil.

\section{Conclusions}

A long-term sustainable agriculture in litchi orchards was not necessarily beneficial to soil health, resulting in low $\mathrm{pH}$ and phosphorus of soil. However, the application of chemical fertilizer will accelerate soil acidification and cause serious damage to the soil. Our results indicated that the soil enzymatic activity including acid phosphatase, arylsulfatase, $\beta$-glucosidase, urease, and nitrogen fixation was significantly influenced by the temporal change in the litchi orchards. Also, the significant effect of agricultural management across time on the arylsulfatase, $\beta$-glucosidase, and urease was observed. Regarding the bacterial community, no interaction of agricultural management and temporal changes on bacterial alpha diversity and dominant phyla was found, but bacterial diversity, Shannon and Simpson, and dominant phyla, Acidobacteria 
and Proteobacteria, were significantly influenced by time. These results suggested that soil enzyme activity was more susceptible to temporal change and agricultural management than that of bacterial richness and diversity. In addition, soil enzymatic activity was widely affected by soil environmental factors due to the dynamics and turn-over times of enzymes variously involved in enzyme-mediated decay with their function and origin. By contrast, soil pH directly affecting extractable elements could fluctuate the bacterial richness and diversity. Nevertheless, it was difficult to interpret the correlation of dominant phyla with the soil property, which only a significant relationship between Proteobacteria and potassium was perceived. Thus, the temporal change involved in soil property could result in different degrees of impact on soil enzymes and bacteria.

\section{Supplementary Information}

The online version contains supplementary material available at https://doi. org/10.1186/s40529-021-00322-9.

Additional file 1: Figure S1. The map of the litchi orchards including CA and SA managements.

Additional file 2: Figure S2. The Venn chart of OTUs obtained from CA and SA soils of litchi orchards between October 2016 and April 2017.

Additional file 3: Table S1. Agricultural management of litchi orchards by conventional (CA) and sustainable agriculture (SA).

Additional file 4: Table S2. Pearson correlation analysis of soil properties.

Additional file 5: Table S3. $16 \mathrm{~S}$ rRNA reads summary of soil DNA obtained from CA and SA soils of litchi orchards between October 2016 and April 2017 according to the Illumina MiSeq analysis.

Additional file 6: Table S4. Significance of $p$-value for repeated measures ANOVA on bacterial distribution including Acidobacteria, Actinobacteria, Bacteroidetes, Chloroflexi, and Proteobacteria.

Additional file 7: Table S5. Significance of $p$-value for repeated measures ANOVA on alpha diversity of bacteria including SOBS, Chao, ACE, Shannon, and Simpson indices.

Additional file 8: Table S6. Pearson correlation between enzymatic activity, bacterial community, and soil properties.

Additional file 9: Table S7. Modeling the enzymatic activity and bacterial community with soil chemical properties and dominant bacteria by multivariate linear regression ANOVA with the stepwise method.

Additional file 10: Table S8. Pearson correlation between temperature, relative humidity, and bacterial community.

Additional file 11: Table S9. Pearson correlation between temperature, relative humidity, and enzymatic activity.

\section{Acknowledgements}

The experiments were assisted by the Agricultural Research Institute, Council of Agriculture, Executive Yuan, Taiwan. The detailed methodology of soil bacterial 165 rDNA amplicon sequencing was provided by BGI, Shenzhen.

\section{Authors' contributions}

Y-PC designed the experiment, analyzed the data, and prepared the writingoriginal draft. C-FT collected the samples and the data. AH and Y-JC analyzed the data and revised the manuscript. C-CY designed the experiment and reviewed the manuscript. All authors read and approved the final manuscript.

\section{Funding}

This work was supported by the Ministry of Science and Technology, Taiwan (MOST 106-2621-M-005-002-), and the Innovation and Development Center of Sustainable Agriculture from The Featured Areas Research Center Program within the framework of the Higher Education Sprout Project by the Ministry of Education (MOE) in Taiwan.

\section{Availability of data and materials}

The data used and analyzed in this study can be provided from the corresponding author for scientific, non-profit purpose.

\section{Declarations}

Ethics approval and consent to participate

Not applicable, the study involves no human participants.

\section{Consent for publication}

Not applicable.

\section{Competing interests}

The authors declare that they have no competing interests.

\section{Author details}

${ }^{1}$ Department of Public Health and Medical Technology, Xiamen Medical College, Xiamen 361023, Fujian, China. ${ }^{2}$ Engineering Research Center of Natural Cosmeceuticals College of Fujian Province, Xiamen Medical College, Xiamen 361023, Fujian, China. ${ }^{3}$ Department of Soil and Environmental Sciences, National Chung Hsing University, Taichung 40227, Taiwan. ${ }^{~}$ Bioresource Collection and Research Center, Food Industry Research and Development Institute, Hsinchu 300, Taiwan. ${ }^{5}$ Innovation and Development Center of Sustainable Agriculture, National Chung Hsing University, Taichung 40227, Taiwan.

Received: 10 June 2021 Accepted: 14 September 2021

Published online: 26 September 2021

\section{References}

Arcand MM, Levy-Booth DJ, Helgason BL (2017) Resource legacies of organic and conventional management differentiate soil microbial carbon use. Front Microbiol 8:2293

Armstrong A, Valverde A, Ramond JB, Makhalanyane TP, Jansson JK, Hopkins DW, Aspray TJ, Seely M, Trindade MI, Cowan DA (2016) Temporal dynamics of hot desert microbial communities reveal structural and functional responses to water input. Sci Rep 6:34434

Bakker MG, Looft T, Alt DP, Delate K, Cambardella CA (2018) Bulk soil bacterial community structure and function respond to long-term organic and conventional agricultural management. Can J Microbiol 64:901-914

Barron AR, Wurzburger N, Bellenger JP, Wright SJ, Kraepiel AM, Hedin LO (2008) Molybdenum limitation of asymbiotic nitrogen fixation in tropical forest soils. Nat Geosci 2:42-45

Booth IR (1985) Regulation of cytoplasmic pH in bacteria. Microbiol Rev 49:359-378

Bronick C, Lal R (2005) Soil structure and management: a review. Geoderma 124:3-22

Buscardo E, Geml J, Schmidt SK, Freitas H, da Cunha HB, Nagy L (2018) Spatio-temporal dynamics of soil bacterial communities as a function of Amazon forest phenology. Sci Rep 8:4382

Caporaso JG, Lauber CL, Walters WA, Berg-Lyons D, Huntley J, Fierer N, Owens SM, Betley J, Fraser L, Bauer M, Gormley N, Gilbert JA, Smith G, Knight $\mathrm{R}$ (2012) Ultra-high-throughput microbial community analysis on the Illumina HiSeq and MiSeq platforms. ISME J 6:1621-1624

Chen YP, Rekha PD, Arun AB, Shen FT, Lai WA, Young CC (2006) Phosphate solubilizing bacteria from subtropical soil and their tricalcium phosphate solubilizing abilities. Appl Soil Ecol 34:33-41

Chen H, Xia Q, Yang T, Shi W (2018) Eighteen-year farming management moderately shapes the soil microbial community structure but promotes habitat-specific taxa. Front Microbiol 9:1776

Cole JR, Wang Q, Fish JA, Chai B, McGarrell DM, Sun Y, Brown CT, PorrasAlfaro A, Kuske CR, Tiedje JM (2014) Ribosomal Database Project: 
data and tools for high throughput rRNA analysis. Nucleic Acids Res 42:D633-D642

Dai L, Liu C, Yu L, Song C, Peng L, Li X, Tao L, Li G (2018) Organic matter regulates ammonia-oxidizing bacterial and archaeal communities in the surface sediments of Ctenopharyngodon idellus aquaculture ponds. Front Microbiol 9:2290

DeSantis TZ, Hugenholtz P, Larsen N, Rojas M, Brodie EL, Keller K, Huber T, Dalevi D, Hu P, Andersen GL (2006) Greengenes, a chimera-checked 16S rRNA gene database and workbench compatible with ARB. Appl Environ Microbiol 72:5069-5072

Edgar RC, Haas BJ, Clemente JC, Quince C, Knight R (2011) UCHIME improves sensitivity and speed of chimera detection. Bioinformatics 27:2194-2200

Edgar RC (2013) UPARSE: highly accurate OTU sequences from microbial amplicon reads. Nat Methods 10:996-998

Eivazi F, Tabatabai MA (1988) Glucosidases and galactosidases in soils. Soil Biol Biochem 20:601-606

Fatemi FR, Fernandez IJ, Simon KS, Dail DB (2016) Nitrogen and phosphorus regulation of soil enzyme activities in acid forest soils. Soil Biol Biochem 98:171-179

Fierer N, Jackson RB (2006) The diversity and biogeography of soil bacterial communities. Proc Natl Acad Sci USA 103:626-631

Hardy RW, Burns RC, Holsten RD (1973) Application of the acetyleneethylene assay for measurement of nitrogen fixation. Soil Biol Biochem $5: 47-81$

Hendershot WH, Lalande H, Reyes D, MacDonald D (2008) Trace element assessment. In: Carter MR, Gregorich EG (eds) Soil sampling and methods of analysis, 2nd edn. CRC Press Taylor \& Francis, Boca Raton

Ho I (1979) Acid phosphatase activity in forest soil. Forest Sci 25:567-568

Ibrahim SR, Mohamed GA (2015) Litchi chinensis: medicinal uses, phytochemistry, and pharmacology. J Ethnopharmacol 174:492-513

Ju Y, Tian H, Zhang R, Zuo L, Jin G, Xu Q, Ding X, Li X, Chu Z (2017) Overexpression of OsHSP18.0-Cl enhances resistance to bacterial leaf streak in rice. Rice (NY) 10:12

Jung J, Yeom J, Han J, Kim J, Park W (2012) Seasonal changes in nitrogencycle gene abundances and in bacterial communities in acidic forest soils. J Microbiol 50:365-373

Kampfer P, Busse HJ, McInroy JA, Xu J, Glaeser SP (2015) Flavobacterium nitrogenifigens sp. nov., isolated from switchgrass (Panicum virgatum) Int J Syst Evol Microbiol 65:2803-2809

Kivlin SN, Hawkes CV (2016) Temporal and spatial variation of soil bacteria richness, composition, and function in a neotropical rainforest. PLoS ONE 11:e0159131

Lammel DR, Barth G, Ovaskainen O, Cruz LM, Zanatta JA, Ryo M, de Souza EM, Pedrosa FO (2018) Direct and indirect effects of a pH gradient bring insights into the mechanisms driving prokaryotic community structures. Microbiome 6:106

Lane DJ. 16S/23S rRNA sequencing. In: Stackebrandt E, Goodfellow M. eds. Nucleic acid techniques in bacterial systematic. Wiley. New York,1991, pp 115-147

Lauber CL, Hamady M, Knight R, Fierer N (2009) Pyrosequencing-based assessment of soil pH as a predictor of soil bacterial community structure at the continental scale. Appl Environ Microbiol 75:5111-5120

Lemanowicz J (2011) Phosphatases activity and plant available phosphorus in soil under winter wheat (Triticum aestivum $\mathrm{L}$.) fertilized minerally. Polish J Agron 4:12-15

Li R, Chen X, Liu Z, Chen Y, Liu C, Ye L, Xiao L, Yang Z, He J, Wang WJ, Qi $H$ (2020) Characterization of gut microbiota associated with clinical parameters in intrahepatic cholestasis of pregnancy. BMC Gastroenterol 20:395

Lin YT, Huang YJ, Tang SL, Whitman WB, Coleman DC, Chiu CY (2010) Bacterial community diversity in undisturbed perhumid montane forest soils in Taiwan. Microb Ecol 59:369-378

Liu Z, Lin Y, Lu H, Ding M, Tan Y, Xu S, Fu S (2013) Maintenance of a living understory enhances soil carbon sequestration in subtropical orchards. PLOS ONE 8:e76950

Magoc T, Salzberg SL (2011) FLASH: fast length adjustment of short reads to improve genome assemblies. Bioinformatics 27:2957-2963

Mandal A, Neenu S (2012) Impact of climate change on soil biodiversity-a review. Agri Rev 33:283-292
Mao Q, Lu X, Zhou K, Chen H, Zhu X, Mori T, Mo J (2017) Effects of long-term nitrogen and phosphorus additions on soil acidification in an $\mathrm{N}$-rich tropical forest. Geoderma 285:57-63

Mark Ibekwe A, Ors S, Ferreira JFS, Liu X, Suarez DL (2017) Seasonal induced changes in spinach rhizosphere microbial community structure with varying salinity and drought. Sci Total Environ 579:1485-1495

Matson AL, Corre MD, Burneo Jl, Veldkamp E (2015) Free-living nitrogen fixation responds to elevated nutrient inputs in tropical montane forest floor and canopy soils of southern Ecuador. Biogeochemistry 122:281-294

McCune B, Grace JB (2002) Analysis of ecological communities. MjM Software Design, Gleneden Beach, Oregon

Morris EK, Caruso T, Buscot F, Fischer M, Hancock C, Maier TS, Meiners T, Muller C, Obermaier E, Prati D, Socher SA, Sonnemann I, Waschke N, Wubet T, Wurst S, Rillig MC (2014) Choosing and using diversity indices: insights for ecological applications from the German Biodiversity Exploratories. Ecol Evol 4:3514-3524

Murphy CA, Foster BL, Gao C (2016) Temporal dynamics in rhizosphere bacterial communities of three perennial grassland species. Agronomy 6:17

Park HJ, Chae N, Sul WJ, Lee BY, Lee YK, Kim D (2015) Temporal changes in soil bacterial diversity and humic substances degradation in subarctic tundra soil. Microb Ecol 69:668-675

Pettit NM, Gregory LJ, Freedman RB, Burns RG (1977) Differential stabilities of soil enzymes. Assay and properties of phosphatase and arylsulphatase. Biochim Biophys Acta 485:357-366

Qin J, Li Y, Cai Z, Li S, Zhu J, Zhang F, Liang S, Zhang W, Guan Y, Shen D, Peng Y, Zhang D, Jie Z, Wu W, Qin Y, Xue W, Li J, Han L, Lu D, Wu P, Dai Y, Sun X, Li Z, Tang A, Zhong S, Li X, Chen W, Xu R, Wang M, Feng Q, Gong M, Yu J, Zhang Y, Zhang M, Hansen T, Sanchez G, Raes J, Falony G, Okuda S, Almeida M, LeChatelier E, Renault P, Pons N, Batto JM, Zhang Z, Chen H, Yang R, Zheng W, Li S, Yang H, Wang J, Ehrlich SD, Nielsen R, Pedersen O, Kristiansen K, Wang J (2012) A metagenome-wide association study of gut microbiota in type 2 diabetes. Nature 490:55-60

Rasche F, Knapp D, Kaiser C, Koranda M, Kitzler B, Zechmeister-Boltenstern S, Richter A, Sessitsch A (2011) Seasonality and resource availability control bacterial and archaeal communities in soils of a temperate beech forest. ISME J 5:389-402

Ray PK (2002) Breeding tropical and subtropical fruits, vol 6. Springer, Berlin

Schimel J, Becerra CA, Blankinship J (2017) Estimating decay dynamics for enzyme activities in soils from different ecosystems. Soil Biol Biochem 114:5-11

Shen C, Shi Y, Fan K, He JS, Adams JM, Ge Y, Chu H (2019) Soil pH dominates elevational diversity pattern for bacteria in high elevation alkaline soils on the Tibetan Plateau. FEMS Microbiol Ecol 95:fiz003

Shigyo N, Umeki K, Hirao T (2019) Seasonal dynamics of soil fungal and bacterial communities in cool-temperate montane Forests. Front Microbiol 10:1944

Tabatabai MA (1982) Soil enzyme. In: Page AL (ed) Methods of soil analysis, Part 2. Chemical and microbiological properties. No. 9. Agronomy Monograph, Madison

Tabatabai MA, Bremner JM (1970) Arylsulfatase activity of soils. Soil Sci Soc Am J 34.225-229

Tamm CO, Hallbäcken L (1986) Changes in soil ph over a 50-year period under different forest canopies in SW Sweden. Water Air Soil Pollut 31:337-341

Tullus A, Kupper P, Sellin A, Parts L, Sober J, Tullus T, Lohmus K, Sober A, Tullus H (2012) Climate change at northern latitudes: rising atmospheric humidity decreases transpiration, N-uptake and growth rate of hybrid aspen. PLoS One 7:e42648

Vitousek PM, Porder S, Houlton BZ, Chadwick OA (2010) Terrestrial phosphorus limitation: mechanisms, implications, and nitrogen-phosphorus interactions. Ecol Appl 20:5-15

Xian Y, Wang M, Chen W (2015) Quantitative assessment on soil enzyme activities of heavy metal contaminated soils with various soil properties. Chemosphere 139:604-608

Xie X, Pu L, Wang Q, Zhu M, Xu Y, Zhang M (2017) Response of soil physicochemical properties and enzyme activities to long-term reclamation of coastal saline soil, Eastern China. Sci Total Environ 607-608:1419-1427 
Yang M, Yang D, Yu X (2018) Soil microbial communities and enzyme activities in sea-buckthorn (Hippophae rhamnoides) plantation at different ages. PLoS ONE 13:e0190959

Zhang Y, Li Q, Chen Y, Dai Q, Hu J (2019) Dynamic change in enzyme activity and bacterial community with long-term rice cultivation in mudflats. Curr Microbiol 76:361-369

Zhao J, Ni T, Li J, Lu Q, Fang Z, Huang Q, Zhang R, Li R, Shen B, Shen Q

(2016) Effects of organic-inorganic compound fertilizer with reduced chemical fertilizer application on crop yields, soil biological activity and bacterial community structure in a rice-wheat cropping system. Appl Soil Ecol 99:1-12

\section{Publisher's Note}

Springer Nature remains neutral with regard to jurisdictional claims in published maps and institutional affiliations.
Submit your manuscript to a SpringerOpen ${ }^{\circ}$ journal and benefit from:

- Convenient online submission

- Rigorous peer review

- Open access: articles freely available online

- High visibility within the field

- Retaining the copyright to your article

Submit your next manuscript at $\boldsymbol{\nabla}$ springeropen.com 